\title{
N-ACETYL- $\beta$-GLUCOSAMINIDASE ACTIVITY IN SERUM DURING PREGNANCY
}

\author{
BY \\ P. G. WALKER, MARY E. WOOLLEN, AND DOREEN PUGH \\ From the Department of Biochemistry, Institute of Orthopaedics, Royal National Orthopaedic Hospital, \\ Stanmore, Middlesex
}

(RECEIVED FOR PUBLICATION MARCH 13, 1960)

A spectrophotometric method for the estimation of $\mathrm{N}$-acetyl- $\beta$-glucosaminidase in serum has been devised. Sera from normal adult males and females showed similar levels of activity.

The activity in serum rose progressively during pregnancy and fell rapidly after parturition to normal levels. This change resembled closely that which occurs in serum $\beta$-glucuronidase.

Placenta showed a moderate and chorion a high level of $\mathrm{N}$-acetyl- $\beta$-glucosaminidase. High $\mathrm{N}$-acetyl- $\beta$-glucosaminidase activity was demonstrated histochemically in decidual cells.

The functions of $\mathrm{N}$-acetyl- $\beta$-glucosaminidase and $\beta$-glucuronidase and factors influencing their activity are discussed.

Enzymes which hydrolyse glycosides of $\mathrm{N}$-acetylglucosamine occur in a wide variety of biological material. It is probable that their function in vivo is to break down oligosaccharides derived from aminopolysaccharides such as hyaluronic acid, which contains $\beta$-glucosaminide linkages, or heparin, which contains $\alpha$-glucosaminide linkages. Synthetic $\mathrm{N}$-acetyl- $\alpha$ - and $-\beta$-glucosaminides have been prepared and used as substrates for the demonstration of both types of $\mathrm{N}$-acetylglucosaminidase activity in mammalian tissues (Helferich and Iloff, 1933; Roseman and Dorfman, 1951).

Work on the kinetics and specificity of $\mathrm{N}$-acetyl$\beta$-glucosaminidase has been carried out using partially purified preparations of the enzyme from various sources (Watanabe, 1936; Neuberger and Pitt Rivers, 1939; Pugh, Leaback, and Walker, 1957b). Quantitative data concerning the amount of the enzyme in tissues of rat and mouse have recently been published (Conchie, Findlay, and Levvy, 1959). An extensive survey of the distribution of $\mathrm{N}$-acetyl- $\beta$-glucosaminidase in the tissues of the rat has recently been completed in this laboratory and the results are being prepared for publication. High levels of $\mathrm{N}$-acetyl- $\beta$-glucosaminidase in epididymis (Conchie et al., 1956) and the secretions of secondary sex organs (Conchie and Mann, 1957) have been described. Hahn (1946) failed to detect any $\mathrm{N}$-acetyl- $\beta$-glucosaminidase activity in ox serum.

Following the development of improved methods for the estimation of $\mathrm{N}$-acetyl- $\beta$-glucosaminidase (Pugh et al., 1957b) and a study of the factors involved in the estimation of the enzyme in crude tissue preparations (Pugh et al., 1957a), a simple method for the estimation of the activity of $\mathrm{N}$-acetyl$\beta$-glucosaminidase in serum has been devised using $p$-nitrophenyl $\mathrm{N}$-acetyl- $\beta$-glucosaminide (Westphal and Schmidt, 1952) as substrate. A preliminary survey has established the range of $\mathrm{N}$-acetyl- $\beta$ glucosaminidase activity in normal human sera and an increased activity has been observed in sera from pregnant women.

McDonald and Odell (1947) described changes in the activity of $\beta$-glucuronidase in serum during pregnancy. The activity of this enzyme rose from about the third month of pregnancy, reached its highest level in the last few weeks, and fell rapidly to within normal limits after parturition. The activity of $\beta$-glucuronidase in cord serum and in homogenates of placenta and endometrial tissue gave no indication of the source of the increased activity in serum during pregnancy. The changes in serum $\mathrm{N}$-acetyl- $\beta$-glucosaminidase activity described in this paper are similar to those which have been described in the case of $\beta$-glucuronidase. Evidence is presented which indicates that decidual tissue may be the source of the increased level of $\mathrm{N}$-acetyl- $\beta$-glucosaminidase in serum and the results are discussed in relation to other work on the functions of the two enzymes.

\section{Methods}

Preparation of Substrates.-Phenyl, $p$-nitrophenyl, and $\alpha$-naphthyl $\mathbf{N}$-acetyl- $\beta$-D-glucosaminides were prepared by the method of Leaback and Walker (1957).

Estimation of N-Acetyl- $\beta$-glucosaminidase in Serum.The absorption of $p$-nitrophenyl liberated by $\mathrm{N}$-acetyl $-\beta$ - 
glucosaminidase from $p$-nitrophenyl $\mathrm{N}$-acetyl- $\beta$-glucosamide was estimated in alkaline solution at $400 \mathrm{~m} \mu$ in a " unicam" SP 500 spectrophotometer. The absorption of unhydrolysed substrate at this wavelength is negligible. The following technique was adopted on the basis of the kinetic experiments described below.

Tubes containing substrate $(3.6 \mathrm{mM})$, citrate buffer $(0.05 \mathrm{M}, \mathrm{pH} 4.3)$, and serum $(0.1 \mathrm{ml}$.) in a final volume of $1.0 \mathrm{ml}$. were incubated at $37^{\circ}$ for $30 \mathrm{~min}$. Control tubes in which serum or substrate was omitted were also incubated. Each estimation was carried out in duplicate. At the end of the incubation period the reaction was stopped and the colour of the liberated $p$-nitrophenol developed by the addition of $2 \mathrm{ml}$. $0.25 \mathrm{M} \mathrm{Na} \mathrm{Na}_{3}$. Readings were stable for at least two hours after addition of $\mathrm{Na}_{2} \mathrm{CO}_{3}$ provided the tubes were protected from light. Photo-catalysed decomposition of substrate can be


$\mathrm{Na}_{2} \mathrm{CO}_{8}$ for stopping the reaction (J. W. Woollen, private communication). After correction for serum and substrate blanks the amount of $p$-nitrophenol liberated by the enzyme was read from a calibration curve constructed with a standard solution of $p$-nitrophenol. One unit of $\mathbf{N}$-acetyl- $\beta$-glucosaminidase is defined as the amount of enzyme which will liberate $1 \mathrm{mg}$. of $p$-nitrophenol under the above conditions. Thus defined, units of $\mathrm{N}$-acetyl- $\beta$ glucosaminidase per $100 \mathrm{ml}$. serum equal $\mu \mathrm{g}$. $p$-nitrophenol liberated per tube.

Serum was used for all the estimations reported. $\mathrm{N}$-acetyl- $\beta$-glucosaminidase in serum is stable for several hours at room temperature and for several days at $0-4^{\circ}$. In a small series of observations the activities of $\mathrm{N}$-acetyl$\beta$-glucosaminidase in serum and heparinized plasma prepared from the same specimen of blood agreed within $\pm 10 \%$.

Estimation of $\mathbf{N}$-Acetyl- $\beta$-glucosaminidase in Tissues.Portions of freshly delivered placentae and membranes were blotted and weighed. After sampling the combined membranes an incision was made at the insertion of the umbilical cord and the amnion was stripped from the placenta and chorion. The tissues were ground with water for $1 \mathrm{~min}$. in a glass homogenizer and diluted to give a concentration of $1 \%(\mathrm{w} / \mathrm{v})$. $\mathrm{N}$-acetyl- $\beta$-glucosaminidase activity was estimated by the method of Pugh et al. $(1957 \mathrm{a}, \mathrm{b})$ using phenyl $\mathrm{N}$-acetyl- $\beta$-glucosaminide as substrate. An aliquot of each homogenate was dried at $110^{\circ}$ to constant weight.

Localization of $\mathbf{N}$-Acetyl- $\beta$-glucosaminidase in Tissue Sections.- The histochemical reaction, which depends on the liberation of $\alpha$-naphthol by the enzyme from $\alpha$ naphthyl $\mathrm{N}$-acetyl- $\beta$-glucosaminide and its precipitation in the section as insoluble azo-dye by "simultaneous" coupling with diazotized $o$-aminazotoluene, was carried out as described by Pugh and Walker (1958). The fixed tissues were embedded in gelatin (Pearse, 1953) before sectioning.

\section{Results}

Kinetic Experiments.-The effect of $p \mathrm{H}$ on the rate of hydrolysis of $p$-nitrophenyl $\mathrm{N}$-acetyl- $\beta$ glucosaminide was studied in $0.05 \mathrm{M}$ citrate buffer over the range $p H$ 3.8-5.5. A smooth curve with a single $p H$ optimum at 4.3 was obtained. The rate of

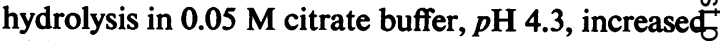
with increasing substrate concentration over the range 0.15 to $6 \mathrm{mM}$. $\mathrm{Km}$ for $p$-nitrophenyl $\mathrm{N}$-acetyl $\beta$-glucosaminide, derived by the method of Line weaver and Burk (1934), was $0.76 \mathrm{mM}$. At the substrate concentration selected for routine use $(3.6 \mathrm{mM})^{s}$ the reaction velocity was nearly maximal. The $\overrightarrow{0}$ amount of $p$-nitrophenol liberated from $3.6 \mathrm{mM}$ $p$-nitrophenyl $\mathrm{N}$-acetyl- $\beta$-glucosamide in $0.05 \mathrm{M \omega}$ citrate, $p \mathrm{H} 4.3$, was shown to be proportional to the amount of serum present (range $0.1-0.4 \mathrm{ml}$.) and to the duration of the period of incubation employed $\vec{\omega}$ (range 15-60 $\mathrm{min}$.).

N-Acetyl- $\beta$-glucosaminidase Activity in Humanw Serum.-Table I shows the results of estimations on음 sera from normal adult males and females (ages-

TABLE I

N-ACETYL- $\beta$-GLUCOSAMINIDASE ACTIVITY IN SERUMOF NORMAL ADULTS

\begin{tabular}{|c|c|c|c|}
\hline & \multicolumn{2}{|c|}{$\begin{array}{l}\text { N-Acetyl- } \beta \text {-glucosaminidase } \\
\text { Activity (units } / 100 \mathrm{ml} \text {. serum) }\end{array}$} & \multirow{2}{*}{$\begin{array}{c}\text { No. of } \\
\text { Observations }\end{array}$} \\
\hline & $\operatorname{Mean}_{ \pm}$S.E. & Range & \\
\hline $\begin{array}{l}\text { Males } \\
\text { Females }\end{array}$ & $\begin{array}{l}6 \cdot 6 \pm 1 \cdot 5 \\
6 \cdot 3 \pm 2 \cdot 0\end{array}$ & $\begin{array}{l}5 \cdot 1-9 \cdot 6 \\
3 \cdot 6-11 \cdot 3\end{array}$ & 20 \\
\hline
\end{tabular}

18-50 years). There was no significant difference $\overrightarrow{\overline{0}}$ between the means of the two groups. Table $\mathrm{II}_{5}^{\mathrm{S}}$ shows that in five normal subjects only slight variations in activity of serum $\mathrm{N}$-acetyl- $\beta$-glucosaminidase

TABLE II

VARIATION IN N-ACETYL- $\beta$-GLUCOSAMINIDASE ACTIVITY OF SERUM DURING NORMAL MENSTRUAL CYCLE

\begin{tabular}{|c|c|c|c|c|c|}
\hline \multirow{2}{*}{$\begin{array}{l}\text { Day of } \\
\text { Cycle }\end{array}$} & \multicolumn{5}{|c|}{$\begin{array}{l}\text { N-Acetyl- } \beta \text {-glucosaminidase Activity* } \\
\text { (units } / 100 \mathrm{ml} \text {. serum) }\end{array}$} \\
\hline & $\mathbf{A}$ & $\mathbf{B}$ & C & $\mathbf{D}$ & $\mathbf{E}$ \\
\hline $\begin{array}{r}1 \\
5 \\
14 \\
21 \\
26\end{array}$ & $\begin{array}{l}6.8 \\
5.6 \\
5.9 \\
5.4 \\
5 \cdot 3\end{array}$ & $\begin{array}{l}8 \cdot 7 \\
8 \cdot 1 \\
7 \cdot 2 \\
7 \cdot 3 \\
8 \cdot 7\end{array}$ & $\begin{array}{l}7 \cdot 4 \\
6.6 \\
6 \cdot 9 \\
6 \cdot 4 \\
7 \cdot 2\end{array}$ & $\begin{array}{l}6.5 \\
9.1 \\
8 \cdot 8 \\
7.4 \\
6 \cdot 1\end{array}$ & $\begin{array}{l}5 \cdot 3 \\
6 \cdot 2 \\
7 \cdot 1 \\
7 \cdot 5 \\
-\end{array}$ \\
\hline
\end{tabular}

occurred during the course of the menstrual cycleso The results of estimations in sera from 120 normako pregnant women are shown in Table III. The? subjects were unselected with regard to age and parity. Serial observations on individual subjectso were not made. The mean $\mathrm{N}$-acetyl- $\beta$-glucosaminidase activity of serum rose throughout pregnancy $\mathbb{Q}$ The increase was logarithmic, the activity beingo approximately double in each trimester. Eight days after delivery serum activity had declined to neato 
TABLE III

VARIATION IN N-ACETYL- $\beta$-GLUCOSAMINIDASE ACTIVITY OF SERUM DURING NORMAL PREGNANCY

\begin{tabular}{|c|c|c|c|}
\hline \multirow{2}{*}{$\begin{array}{l}\text { Duration of } \\
\text { Pregnancy } \\
\text { (weeks) }\end{array}$} & \multicolumn{2}{|c|}{$\begin{array}{c}\text { N-Acetyl- } \beta \text {-glucosaminidase } \\
\text { Activity (units } / 100 \mathrm{ml} \text {. serum) }\end{array}$} & \multirow{2}{*}{$\begin{array}{l}\text { No. of } \\
\text { Observations }\end{array}$} \\
\hline & Mean \pm S.E. & Range & \\
\hline $\begin{array}{r}9-12 \\
13-16 \\
17-20 \\
21-24 \\
25-28 \\
29-32 \\
33-36 \\
37-40\end{array}$ & $\begin{array}{l}13.9 \pm 1 \cdot 1 \\
14.8 \pm 4.4 \\
13.5 \pm 5 \cdot 1 \\
23.9 \pm 12.3 \\
28.8 \pm 13.3 \\
38.6 \pm 6.6 \\
42.3 \pm 10.4 \\
48.9 \pm 14.8\end{array}$ & $\begin{array}{r}8 \cdot 3-20 \cdot 5 \\
6 \cdot 8-23 \cdot 8 \\
6 \cdot 2-23 \cdot 1 \\
7.9-51 \cdot 6 \\
15 \cdot 2-54 \cdot 2 \\
31.4-50.0 \\
18 \cdot 2-83 \cdot 7 \\
14 \cdot 7-100 \cdot 7\end{array}$ & $\begin{array}{r}21 \\
14 \\
9 \\
6 \\
6 \\
6 \\
22 \\
21\end{array}$ \\
\hline $\begin{array}{l}8 \text { days } \\
\text { post-partum }\end{array}$ & $10 \cdot 3 \pm 1 \cdot 7$ & $8 \cdot 3-12 \cdot 4$ & 8 \\
\hline
\end{tabular}

TABLE IV

N-ACETYL- $\beta$-GLUCOSAMINIDASE ACTIVITY IN MATERNAL SERUM DURING LABOUR AND PUERPERIUM AND IN CORD SERUM

\begin{tabular}{|c|c|c|c|c|c|c|c|c|}
\hline \multirow{3}{*}{$\begin{array}{l}\text { Maternal serum } \\
\text { In labour } \\
\text { Puerperium (days) }\end{array}$} & \multicolumn{8}{|c|}{$\begin{array}{l}\text { N-Acetyl- } \beta \text {-glucosaminidase Activity } \\
\text { (units } / 100 \mathrm{ml} \text {. serum) }{ }^{*}\end{array}$} \\
\hline & $\mathbf{A}$ & B & C & D & $\mathbf{E}$ & $\mathbf{F}$ & G & $\mathbf{H}$ \\
\hline & $42 \cdot 0$ & 52.4 & $78 \cdot 0$ & $38 \cdot 2$ & $42 \cdot 4$ & $46 \cdot 6$ & $42 \cdot 6$ & $30 \cdot 3$ \\
\hline $\begin{array}{lll}1 & \ldots & \\
2 & . & \end{array}$ & $\begin{array}{l}17 \cdot 7 \\
12 \cdot 1\end{array}$ & $\begin{array}{l}26 \cdot 2 \\
16.0\end{array}$ & $\begin{array}{l}39 \cdot 2 \\
15 \cdot 0\end{array}$ & $\begin{array}{l}31 \cdot 8 \\
41 \cdot 2\end{array}$ & $\overline{12 \cdot 6}$ & $\overline{19 \cdot 3}$ & $17 \cdot 6$ & 18.4 \\
\hline$\therefore$ & $11 \cdot 3$ & 18.5 & - & $31 \cdot \overline{2}$ & & & & - \\
\hline . & $8 \cdot 3$ & $13 \cdot 3$ & $9 \cdot 2$ & $11 \cdot 5$ & $8 \cdot 8$ & $9 \cdot 3$ & $12 \cdot 4$ & $9 \cdot 5$ \\
\hline$\therefore$ & & & & & & & & \\
\hline Cord serum & $14 \cdot 8$ & $29 \cdot 8$ & $17 \cdot 8$ & $11 \cdot 2$ & $16 \cdot 0$ & $9 \cdot 1$ & 14.4 & $10 \cdot 9$ \\
\hline
\end{tabular}

* Serial specimens were obtained from subjects $A-H$ at the indicated times.

the normal level. This rapid fall was studied in more detail in a small group of patients from whom sera specimens were obtained in labour and during the puerperium (Table IV). With one exception, the decline in serum $\mathrm{N}$-acetyl$\beta$-glucosaminidase activity was most rapid during the first 48 hours after delivery. In subject $D$ the fall did not take place till after the fourth day of the puerperium. Changes in activity between the eighth and twelfth days were only slight. In this group of cases $\mathrm{N}$-acetyl- $\beta$-glucosaminidase activity in serum from cord blood was also estimated. The results show that the activity in foetal serum was in each case considerably lower than that of the corresponding maternal specimen obtained during labour. The mean activity of foetal sera (15.5 units $/ 100 \mathrm{ml}$.) was, however, higher than that of normal adults (Table I). In Fig. 1 the mean serum $\mathrm{N}$-acetyl- $\beta$-glucosaminidase activity (data from Table III) is plotted against duration of pregnancy. Activities have been expressed as percentages of the activity at term in order that they may be compared with similar data provided by McDonald and Odell (1947) for the activity of $\beta$-glucuroni- dase in serum during pregnancy. The extent and course of the changes in the activity of the two enzymes are very similar.

Activity of $\mathrm{N}$-Acetyl- $\beta$-glucosaminidase in Tissues. - $\mathrm{N}$-acetyl- $\beta$-glucosaminidase activities of human placenta and foetal membranes were investigated since these tissues are possible sources of the high serum activity found in association with pregnancy. The results are shown in Table V. Activity was present in both placenta and membranes and most of the activity in the latter was associated with the

TABLE V

N-ACETYL- $\beta$-GLUCOSAMINIDASE ACTIVITY OF PLACENTA AND FOETAL MEMBRANES

\begin{tabular}{|c|c|c|}
\hline Tissue* & $\begin{array}{l}\text { N-Acetyl- } \beta \text {-glucosaminidase } \\
\text { Activity ( } \mu \text { g. phenol liber- } \\
\text { ated } / \mathrm{mg} \text {. dry weight tissue) }\end{array}$ & $\begin{array}{l}\text { Dry Weight of } \\
\text { Tissue } \\
\text { (\% we: weight) }\end{array}$ \\
\hline $\begin{array}{l}\text { Placenta (8) } \\
\text { Combined } \\
\text { membranes (8) } \\
\text { Amnion (6) .. } \\
\text { Chorion (6) }\end{array}$ & $\begin{array}{r}68 \cdot 1 \\
130 \cdot 2 \\
17 \cdot 6 \\
193 \cdot 5\end{array}$ & $\begin{array}{l}17 \cdot 2 \\
12 \cdot 9 \\
12 \cdot 5 \\
12 \cdot 5\end{array}$ \\
\hline
\end{tabular}

* Results are the mean of the number of observations shown in parenthesis.

outer chorionic layer. The activities are referred to a dry weight basis since these tissues contain relatively large amounts of water. No data for $\mathrm{N}$-acetyl$\beta$-glucosaminidase activity of other human tissues are available, but in comparison with normal rat tissues the activity of placenta was moderate, similar to that of liver or spleen, while the activity of chorion

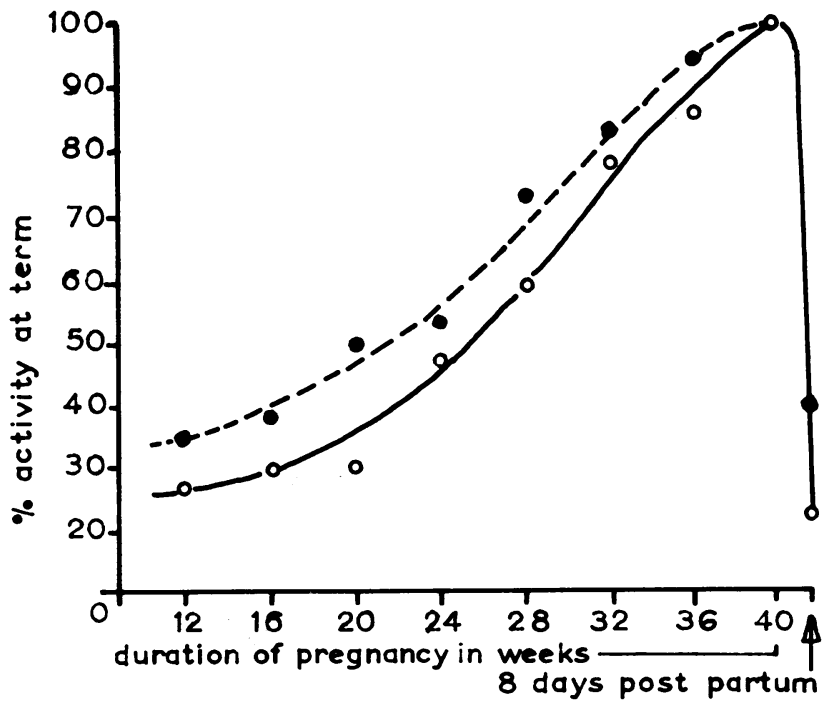

Fig. 1.-Variation in mean $\mathrm{N}$-acetyl- $\beta$-glucosaminidase (O__ $\mathbf{O})$ and $\beta$-glucuronidase ( - - - ) activity of serum during normal pregnancy. Activities expressed as $\%$ activity at term. Data for $\beta$-glucuronidase from McDonald and Odell (1947). 
was high, similar to that of epididymis, the most active of the normal rat tissues (Conchie et al., 1956).

Localization of $\mathbf{N}$-Acetyl- $\beta$-glucosaminidase in Tissues.-The histochemical localization of $\mathrm{N}$-acetyl$\beta$-glucosaminidase in formalin-fixed gelatin-embedded placenta and membranes is shown in Fig. 2a and $b$. Decidual cells in the basal and chorionic plates of the placenta and on the maternal surface of
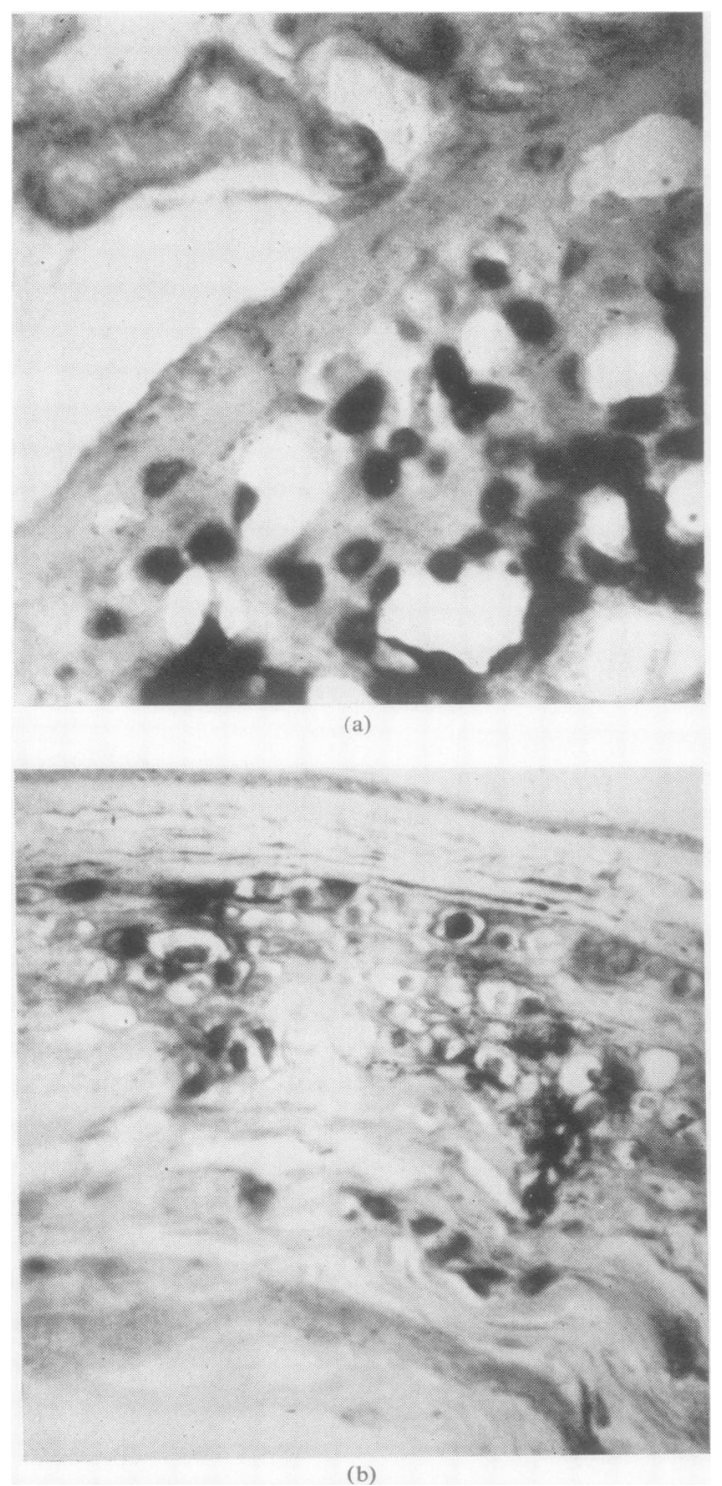

FIG. 2.-Localization of $\mathrm{N}$-acetyl- $\beta$-glucosaminidase in (a) basal plate of placenta and (b) foetal membranes. Decidual cells in both sections contain a heavy deposit of azo-dye indicating high enzyme activity. $\times 150$. the chorion show an intense reaction. Amnion, $\stackrel{ }{-}$ chorionic connective tissue, and placental villi are $\underset{\vec{S}}{\vec{\rho}}$ much less active.

Distribution of $\mathbf{N}$-Acetyl- $\beta$-glucosaminidase in $\frac{\bar{\sigma}}{\bar{\sigma}}$ Whole Blood.-Experiments were carried out to test $\frac{\bar{\omega}}{\vec{\sigma}}$ the possibility that the $\mathrm{N}$-acetyl- $\beta$-glucosaminidase $\stackrel{\varnothing}{\varrho}$ activity of serum might be affected by haemolysis or $\approx$ by leakage of enzyme from cells during the separa- $\vec{A}$ tion of serum. The experiments were technically unsatisfactory, but are described briefly because they $\vec{\omega}$

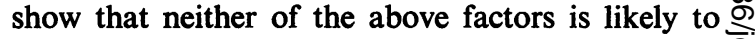
have influenced the results obtained. Plasma and a $\frac{8}{8}$ frozen-thawed suspension of saline-washed cells $\vec{\omega}$ were prepared from heparinized blood. The $\stackrel{\oplus}{\oplus}$ standard assay method had to be modified because $\omega_{\text {o }}$ of the high blanks given by whole blood or cell sus- $\omega$ pension. Trichloroacetic acid was used to stop the $ᄋ$ enzyme reaction and the reaction mixture as depro- $\vec{c}$ teinized by centrifuging. $p$-Nitrophenol in an aliquot $\stackrel{\complement}{\varsigma}$ of the supernatant was estimated after addition of $\mathrm{Na}_{2} \mathrm{CO}_{3}$. The recovery of $p$-nitrophenol in the super- $\mathscr{\theta}$ natant was only $75-85 \%$ complete, the remainder. being adsorbed on to the precipitated protein. The results obtained, however, showed that in normal subjects about $90 \%$ of the $\mathrm{N}$-acetyl- $\beta$-glucosaminidase in whole blood was in the plasma and only slight activity was found in the blood cell suspension. $\stackrel{2}{\mathbb{D}}$

\section{Discussion}

The interpretation of these observations is necessarily speculative. It is usually assumed that an increase in the activity of an enzyme in serum reflects an increased level of production by tissues. The significance of the moderate $\mathrm{N}$-acetyl- $\beta$-glucosamini- $\frac{}{3}$ dase activity of placenta and the high level in the foetal membranes is difficult to assess because no estimations on other tissues from normal or pregnant human subjects have yet been carried out. However, $\frac{9}{5}$ the intense activity of $\mathrm{N}$-acetyl- $\beta$-glucosaminidase $\frac{7}{2}$ demonstrated histochemically in decidual cells and the rapid post-partum decline in the level of the $\tilde{N}$ enzyme in maternal serum make it probable that $N$ the changes in activity of serum during pregnancy ${ }_{N}$ are associated with changes in the production of the enzyme by the endometrium.

The parallel changes in activity of $\mathrm{N}$-acetyl- $\beta-6$ glucosaminidase and $\beta$-glucuronidase in serum during pregnancy suggest that they may be related. $\stackrel{+}{+}$ Evidence that the activity of both enzymes is under $\frac{T}{0}$ hormonal control has been provided by the work of $\frac{0}{\mathbb{D}}$

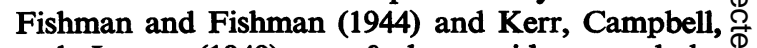

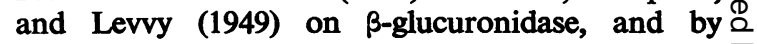
Conchie and Findlay (1959), who showed that low levels of $\mathrm{N}$-acetyl- $\beta$-glucosaminidase in ovariecto- 8 mized mouse uterus were restored to normal by루 
administration of oestrone. The changes in activity of these enzymes in serum during pregnancy may therefore reflect a hormonally conditioned alteration in tissue activity. The validity of the hypothesis of McDonald and Odell (1947) that the increase in $\beta$-glucuronidase activity during pregnancy occurred adaptively in response to the need for increased formation of steroid glucuronides is doubtful in the light of recent work, which has shown that $\beta$ glucuronidase is not involved in the synthesis of glucuronide detoxication products (Dutton and Storey, 1954).

In another context, a link between $\mathrm{N}$-acetyl- $\beta$ glucosaminidase and $\beta$-glucuronidase was provided by the work of Linker, Meyer, and Weissmann (1955) on the breakdown of hyaluronic acid. Hyaluronic acid is composed of chains of alternating, glycosidically linked residues of glucuronic acid and $\mathrm{N}$-acetylglucosamine. Hyaluronidase, an "endoglucosaminidase," forms oligosaccharides by the random hydrolysis of $\beta$-glucosaminide linkages within the chain; these are further degraded to monosaccharides by the successive actions of $\beta$-glucuronidase and $\mathrm{N}$-acetyl- $\beta$-glucosaminidase which remove terminal non-reducing sugar residues. Changes in the activity of $\beta$-glucuronidase and $\mathrm{N}$-acetyl- $\beta$ glucosaminidase during pregnancy may be associated with alterations in the metabolism of mucopolysaccharides and of the connective tissue cells from which such ground substances are derived. For example, changes in the extracellular polysaccharide of the symphysis pubis and of the foetal membranes were demonstrated by the work of Frieden and Hisaw (1953) and Harkness and Harkness (1956).
The results described indicate the need for further observations on the $\mathrm{N}$-acetyl- $\beta$-glucosaminidase activity in serum and tissues in different physiological and pathological states. Preliminary figures suggest that the activity of the enzyme in rabbit serum increases during pregnancy, and an attempt will be made to correlate this with changes in tissue levels and histochemical localization.

We wish to thank Dr. J. K. Borooah for assistance with some of the kinetic experiments and Dr. M. Rose and the staff of the Maternity Unit, Edgware General Hospital, for providing clinical material. This work was assisted by grants from the Research Fund of the University of London and the Nuffield Foundation.

\section{REFERENCES}

Conchie, J., and Findlay, J. (1959). J. Endocr., 18, 132. - and Levvy, G. A. (1956). Nature (Lond.), 178, 1469. - (1959). Biochem. J., 71, 318.

- and Mann, T. (1957). Nature (Lond.), 179, 1190.

Dutton, G. J., and Storey, I. D. E. (1954). Biochem. J., 57, 275.

Fishman, W. H., and Fishman, L. W. (1944). J.biol. Chem., 152, 487. Frieden, E. H., and Hisaw, F. L. (1953). Recent Progr. Hormone Res., $8,333$.

Hahn, L. (1946). Ark. Kemi Min. Geol., 21A, No. 1.

Harkness, M. L. R., and Harkness, R. D. (1956). J. Physiol. (Lond.), $132,482$.

Helferich, B., and Iloff, A. (1933). Hoppe-Seylers Z. physiol. Chem., 221, 252 . Kerr, L. M. H., Campbell, J. G., and Levvy, G. A. (1949). Biochem.

Leaback, D. H., and Walker, P. G. (1957). J. chem. Soc., p. 4754.

Lineweaver, H., and Burk, D. (1934). J. Amer. chem. Soc., 56, 658. Linker, A., Meyer, K., and Weissmann, B. (1955). J. biol. Chem., $213,237$.

MCDonald, D. F., and Odell, L. D. (1947). J. clin. Endocr., 7, 535.

Neuberger, A., and Pitt Rivers, R. V. (1939). Biochem. J., 33, 1580.

Pearse, A. G. E. (1953). Histochemistry. Churchill, London.

Pugh, D., Leaback, D. H., and Walker, P. G. (1957a). Biochem. J., 65, 16P.

- 1 (1957b). Ibid., 65, 464.

and Walker, P. G. (1958). Abstr. 4th Int. Cong. Biochem. [Int. Abstr. biol., Suppl. 1958, p. 45 (No. 4-55)]. Vienna, 1958.

Roseman, S., and Dorfman, A. (1951). J. biol. Chem.,191, 607.

Watanabe, K. (1936). J. Biochem. (Tokyo), 24, 315.

Westphal, O., and Schmidt, H. (1952). Justus Liebigs Ann. Chem., $575,84$. 